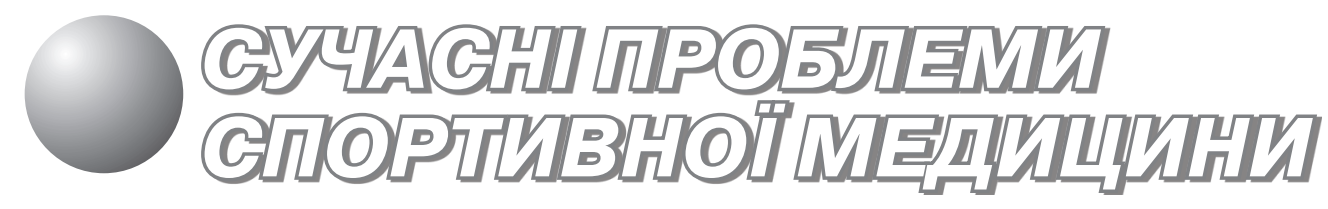

DOI: https://doi.org/10.32652/spmed.2021.2.3-12

\section{Біомеханічний контроль стійкості та рівноваги кваліфікованих спортсменок у черліденгу в дисципліні чер-данс- фристайл-дует методом стабілографії}

\author{
УДК 796.417.071.2:796.012 \\ Г. Андрієнко, О. Шинкарук, Ю. Литвиненко
}

Національний університет фізичного виховання і спорту України, Київ, Україна

\begin{abstract}
Резюме. Мета. Довести ефективність та практичну реалізацію методу стабілографії для контролю виконання техніки рухів у змагальній композиції, а саме стійкості та рівноваги кваліфікованих спортсменок у черліденгу в дисципліні чер-данс-фристайл-дует. Методи. Теоретичні, емпіричні, метод стабілографії. Результати. Аналіз отриманих даних свідчить, що у спортсменок, які спеціалізуються в чер-данс-фристайл-дует, спостерігається середній рівень якості функції рівноваги (60,57-89,21 \%) у пробі з розплющеними очима та низький $(25,86-$ 49,41\%) у пробі із заплющеними очима. Це свідчить про невисокий рівень розвитку зорового аналізатора та низький рівень розвитку пропріорецепторів. На період дослідження спортсменки вивчали нову змагальну програму, в якій особливе місце відводили елементам рівноваги, сенсорній координації. Результати досліджень були враховані при коригуванні процесу підготовки в напрямі підвищення координованості, рівноваги, роботи над пропріорецепторами та зоровим аналізатором. Недостатність сенсомоторної координації може позначатися на порушенні стійкості тіла і системи тіл; просторово-тимчасового орієнтування тіла на опорі і без неї; темпо-ритмовій структурі; диференціюванні параметрів рухів. Для тренувань було запропоновано тренажери рівноваги, які є спеціальними комп'ютерними програмами біологічного зворотного зв'язку, що базуються на візуалізації положення центру тиску або управління певними діями за допомогою переміщення спортсменки. Дані тренажери дозволяють розвивати різні спеціалізовані навички координації балансувальних рухів в основній стійці. Використання тренажерного обладнання зі зворотним біологічним зв'язком дозволило підвищити рівень якості рівноваги, що відзначилося при виконанні нової змагальної вправи: у спортсменок зменшилася кількість помилок при виконанні елементів рівноваги на 34 \%, в парі вони продемонстрували сенсомоторну координацію. Проведені дослідження та багаторічний досвід застосування методу стабілографії свідчать про його високу інформативність для складнокоординаційних видів спорту. Цей метод дозволяє визначити діяльність зорових та пропріорецептивних аналізаторів, що впливають на функцію рівноваги. В черліденгу при складанні змагальної програми важливими елементами є складність і точність рухів, стійкість при виконанні елементів, контроль корпуса і всіх частин тіла під час виконання рухів і елементів, перенесення ваги тіла, максимальне використання простору змагального майданчика, перебудови, взаємодії в парі, згладжені зміни позицій і положень тощо. Поєднання методу контролю за допомогою стабілографії та використання тренажерів рівноваги дозволили спортсменкам підвищити рівень якості рівноваги та зменшити кількість помилок при виконанні змагальної програми.
\end{abstract}

Ключові слова: черліденг, дисципліна чер-данс-фристайл-дует, рівновага, стабілографія, контроль. 
Biomechanical control of stability and balance of qualified athletes in cheerleading
in the discipline of cheer-dance-freestyle-duet by stabilography H. Andriyenko, O. Shynkaruk, Yu. Lytvynenko

National University of Physical Education and Sport of Ukraine, Kyiv, Ukraine

Abstract. Objective. To prove the effectiveness and practical implementation of the method of stabilography to control the performance of movement techniques in the competitive composition, namely the stability and balance of qualified athletes in cheerleading in the discipline of dance-freestyle-duet. Methods. Theoretical methods (theoretical analysis and generalization of data of scientific and methodological literature and data of the Internet, systematization) allowed to conduct a retrospective and modern analysis of the method of stabilography to assess the balance and stability of athletes in complex coordination sports. Empirical research methods (analysis of athletes' data, video analysis, pedagogical observation, testing using the instrumental method of stabilography using the system «Stabilan-01-2», methods of mathematical statistics) allowed to determine the biomechanical indicators of stability and balance of athletes in cheerleading in the discipline of dance. freestyle duo. Results. The analysis of the obtained data shows that the athletes who specialize in cheer-dance-freestyle have an average level of quality of the balance function (60.57-89.21\%) in the sample with open eyes and low (25.86-49.41\%) in the sample with eyes closed. This indicates a low level of development of the visual analyzer, and a low level of development of proprioceptors. During the study period, the athletes studied a new competitive program, in which a special place was given to the elements of balance, sensory coordination. The results of the research were taken into account when adjusting the training process in the direction of improving coordination, balance, work on proprioceptors and visual analyzer. Lack of sensorimotor coordination can affect the stability of the body and body system; spatial - temporary orientation of the body on the support and without it; tempo-rhythmic structure; differentiation of movement parameters. Equilibrium simulators have been proposed for training, which are special computer programs of biological feedback, based on the visualization of the position of the center of pressure or control of certain actions by moving the athlete. These simulators allow you to develop various specialized skills of coordination of balancing movements in the main rack. The use of exercise equipment with biological feedback allowed to improve the quality of balance, which was observed when performing a new competitive exercise: the number of errors in performing elements of balance decreased by $34 \%$, athletes in pairs showed sensorimotor coordination. The conducted researches and long-term experience of application of a method of a stabilography testify to its high informativeness for difficult coordination kinds of sports. This method allows to determine the activity of visual and proprioceptive analyzers that affect the balance function. In cheerleading when compiling a competition program, the important elements are the complexity and accuracy of movements, stability when performing elements, control of the body and all body parts during movements and elements, body weight transfer, maximum use of competition space, adjustment, pair interaction, smoothed changes positions and provisions, etc. The combination of the use of the method of control with the help of stabilography and the use of balance simulators allowed the athletes to improve the quality of balance and reduce the number of errors in the competition program.

Keywords: cheerleading, discipline of cheer-dance-freestyle-duet, balance, stabilography, control.

Постановка проблеми. Черліденг у сучасному спорті стає все більш популярним та посідає чільне місце серед неолімпійських видів спорту. Черліденгу характерна своя система підготовки та змагань, проте йому притаманні загальні характеристики складнокоординаційних та естетичних видів спорту. За визначенням фрахівців, черліденг органічно поєднує в собі елементи шоу, видовищні складні елементи, координаційно складні та інтенсивні рухи з елементами акробатики, спортивної та художньої гімнастики, спортивних танців, хореографії тощо [22, 24]. Активність проведення досліджень науковцями свідчить про зацікавленість практиків та дослідників черліденгом. Цьому сприяють постійне зростання молоді, яка активно займається черліденгом, та високі спортивні результати команд на всеукраїнських і міжнародних змаганнях $[14,15]$.

Підготовка спортсменок та команд у черліденгу потребує наукового обгрунтування раціональних прийомів виконання, виявлення нових методів та способів навчання, які б дозволили їм демонструвати високий рівень технічної майстерності $[5,6,20]$. За даними проведених досліджень $[4,22]$, у черліденгу показано значущість технічної підготовки. Це обумовлено специфікою змагальної діяльності, яка включає в себе як виконання різноманітних рухів самим предметом (кидки і ловля, відбиви, маніпуляції), так і їх поєднання з рухами програми: рівновагами, поворотами, стрибками, нахилами, елементами півакробатики. У процесі підготовки до зма- 
гань особливе місце займають моніторинг стану спортсменок, використання біомеханічних методів оцінювання техніки рухів спортсменок. Дослідження техніки виконання змагальної вправи, утримання рівноваги, виконання рухів у стійкій позі дозволяє тренеру своєчасно коригувати тренувальний процес, змагальну композицію, раціонально вибудовувати структуру рухів, внутрішній взаємозв'язок елементів рухів.

Фахівці у своїх дослідженнях довели, що у видах спорту зі складною координаційною структурою рухів, таких як спортивні види гімнастики, акробатика, стрибки на батуті, фрристайл, черліденг, змагальні вправи виконуються в складних умовах статокінетичної та статодинамічної стійкості [16, 29]. Для вирішення рухових завдань спортсменки управляють положеннями тіла, позами тіла на опорі і без неї. Вони досягають координаційної точності рухових дій у складній фразовій структурі спортивних вправ. Н. А. Бернштейн, В. М. Болобан та N. Sarabon зазначають, що провідна роль в ефективному управлінні руховими діями належить сенсомоторній координації [2, 3, 12, 31]. Це свідчить про необхідність застосування координаційного тренування спортсменок у черліденгу для ефективного виконання технічних дій та змагальної композиції і здійснення моніторингу координації спортсменок (стійкості) у процесі підготовки до змагань.

Мета дослідження - довести ефективність та практичну реалізацію методу стабілографії для контролю виконання техніки рухів у змагальній композиції, а саме стійкості та рівноваги кваліфікованих спортсменок у черліденгу в дисципліні чер-данс-фристайл-дует.

Методи дослідження. Теоретичні методи (теоретичний аналіз та узагальнення даних науково-методичної літератури та даних мережі Інтернет, систематизація) дозволили провести ретроспективний та сучасний аналіз питань застосування методу стабілографії для оцінювання рівноваги і стійкості спортсменок у складнокоординаційних видах спорту.

Емпіричні методи (аналіз даних спортсменок, відеоаналіз, педагогічне спостереження, тестування 3 використанням інструментального методу стабілографії за допомогою системи «Стабілан-01-2», методи математичної статистики) дозволили визначити біомеханічні показники стійкості та рівноваги спортсменок у черліденгу в дисципліні чер-данс-фрристайл-дует [8, 25-27].

Застосування методу стабілографії надає можливість досліджувати статодинамічну стійкість тіла спортсменки і системи тіл; кількісно та якісно оцінити цю стійкість; доповнити знан- ня щодо спортивної техніки вправ; здійснювати контроль якості навчання вправ, пов'язаних зі складною руховою навичкою збереження рівноваги тіла; визначати функціональний стан організму спортсменки за показниками статодинамічної стійкості її тіла, реєструючи стан сенсорних систем і реакцію на тренувальні навантаження за показниками координації ортоградного і перевернутого положення тіла (до тренування, після розминки, після змагальної вправи тощо) $[10,11]$; визначати рівень і динаміку тренованості фрункції балансування в системі взаємодіючих тіл; проводити прогнозування і професійний відбір спортсменок у команду [18].

В основі методу стабілографії - визначення центру тиску (ЦТ) - точки, що локалізується на вертикальній проєкції або векторі [32] реакції опори, тобто ЦТ - рівнодіюча, вироблена масою тіла і його переміщеннями, на стабілометричних або динамометричних платформах.

ЦТ $є$ середнім положенням рівнодіючої тиску тіла на опору в межах площі опори. ЦТ в цілому фрізично не залежить від загального центру мас (ЦМ). Проте при положенні стоячи в стані спокою ЦТ і ЦМ знаходяться на одній вертикалі. 3 певним припущенням можна сказати, що ЦТ вертикальна проєкція ЦМ на площину опори. Якщо одна стопа знаходиться на опорі, то ЦТ буде в межах площі опори даної стопи. Якщо обидві стопи на опорі, то ЦТ буде в деякому місці між стопами, його положення буде залежати від того, яку вагу буде перенесено на ту або іншу нижню кінцівку. Використання стабілограм графіків зміни положення ЦТ у сагітальній і фронтальній площинах у часі в системі координат, що включає положення стоп обстежуваного, дозволило оцінити параметри стійкості та рівноваги спортсменок. Стабілограми - графіки переміщення ЦТ, що представлені як функція від часу для фрронтальної і сагітальної площин. Вісь часу при цьому розташовується горизонтально. Рухи ЦТ вперед і вправо мають позитивне значення по вертикальній осі.

Статокінезіограма - графрічне представлення траєкторії руху ЦТ у проєкції на горизонтальну площину. Може бути представлена у двох системах координат: системі координат платорорми або системі координат обстежуваного [19, 28]. Сама статокінезіограма в системі координат обстежуваного $є$ визначенням становища ЦТ щодо стоп спортсменки та її коливання.

Результати дослідження. У дослідженнях брали участь чотири спортсменки високого класу, які на момент обстеження перебували на етапі безпосередньої підготовки до змагань з 
черліденгу з дисципліни чер-данс-фрристайл-дует (червень 2021 р.). Дані результати досліджень було використано для формування найсильнішого дуету для виступу на змаганнях.

Дослідження проходили на базі науково-дослідного інституту Національного університету фрізичного виховання і спорту з використанням біомеханічного інструментарію «Стабілан-01-2» за участю докт. фріз. вих. Ю. В. Литвиненко.

Методика комп'ютерної стабілографрії включала в себе просту пробу Ромберга в стійкій вертикальній позі: проста проба з розплющеними і заплющеними очима з фіксацією погляду на об'єкті характеризувала якість нервово-м'язової активності і дозволяла оцінити рівень сорормованості навичок рухової сенсорної системи з управління стійкістю тіла $[7,8,17]$. Ця проба була запропонована Ромбергом для якісного визначення змін пропріорецепції. Випробувана стає в положення «стопи разом», очі заплющені. Дослідник візуально визначає стабільність збереження положення тіла. Типовий варіант цього тесту при стабілометрії полягає в тому, що спортсменка залишається в положенні основної стійки, але заплющує очі. Реєстрація стабілограми проводиться при заплющених очах. Сенс використання цього тесту в тому, що при дослідженні виключається вплив зорового аналізатора. Спортсменка зберігає вертикальне положення виключно за рахунок пропріорецепції. Відзначимо, що при фрізіологічній регуляції основної стійки величина коливань тіла людини менше порога, що сприймається вестибулярним апаратом [13, 28].

Для аналізу стійкості пози було використано такі показники коливань ЦТ:

QX i QY (мм) - середньоквадратичне відхилення (розкид) ЦТ у фронтальній і сагітальній площинах; ЦТ;

R (мм) - середній радіус відхилення (розкид)

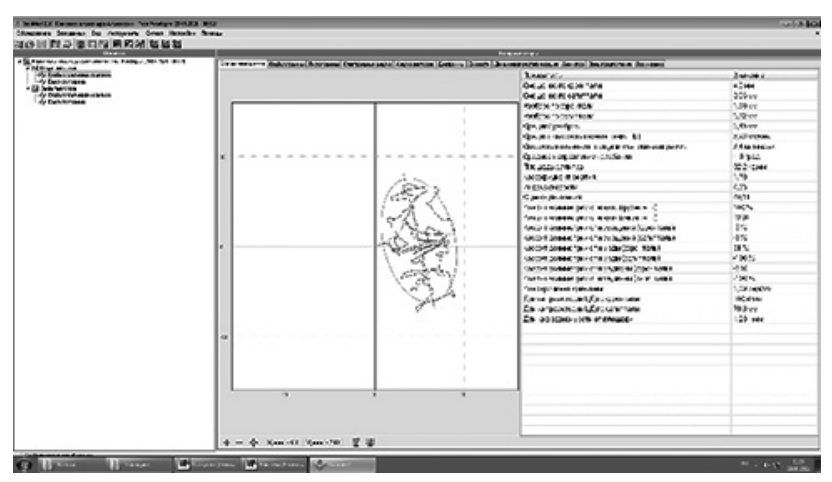

a
V (мм/с) - середня швидкість переміщення Цт;

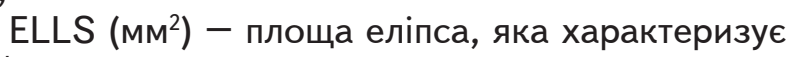
робочу площу опори спортсменки;

LX i LY (мм) - довжина траєкторії ЦТ по фронталі і сагіталі;

КФР (\%) - якість функції рівноваги визначає мінімальну швидкість зміни ЦТ, відображає ступінь стабілокінетичної стійкості тіла (чим вище значення КФР, тим краще спортсменки підтримують рівновагу).

Підготовка спортсменок - членів збірної команди України з черліденгу з дисципліни черданс-фристайл-дует на етапі безпосередньої підготовки до змагань включала три мезоцикли: втягуючий, контрольно-підготовчий та змагальний.

У нашому дослідженні у втягуючому мезоциклі брали участь чотири спортсменки - кандидатки на участь у головних міжнародних змаганнях року. Метою даного мезоциклу було засвоєння нових елементів змагальної композиції, виконання змагальної композиції без помилок, фрормування найсильнішого дуету. 3 цією метою здійснювали моніторинг підготовленості спортсменок, оцінювали морфологічні показники, психологічні та психофізіологічні характеристики, показники стійкості і рівноваги, які є провідними в змагальній композиції спортсменок.

Результати тестування спортсменок методом стабілографрії (проби Ромберга з розплющеними та заплющеними очима) дозволили отримати результати, представлені на рисунках 1-8.

Отримані результати досліджень дозволили розглянути індивідуальні особливості виконання тесту спортсменками.

На рисунках 1, 2 наведено показники статокінезіограми спортсменки $Є$. та графрічне зображення якості функції ії рівноваги при виконанні звичайної проби Ромберга.

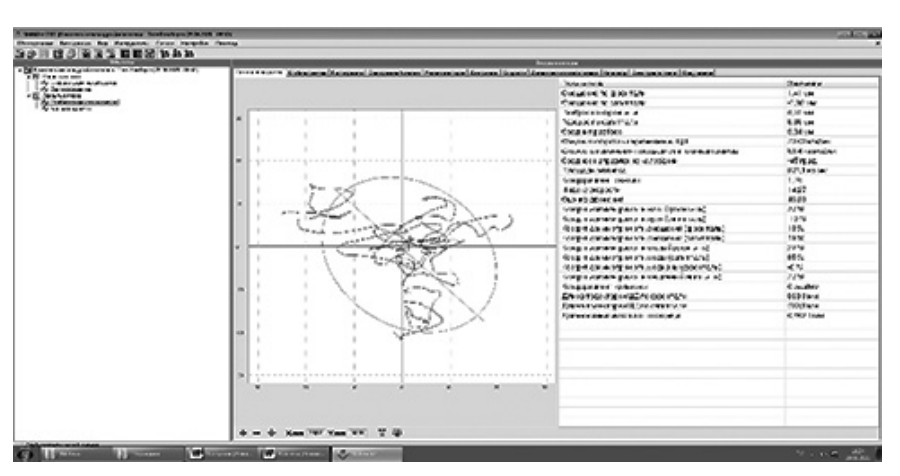

6

Рисунок 1 - Статокінезіограма та їі кількісні показники при виконанні звичайної проби Ромберга спортсменкою Є.: а - очі розплющені; б - очі заплющені (методика «Стабілан-01-2») 


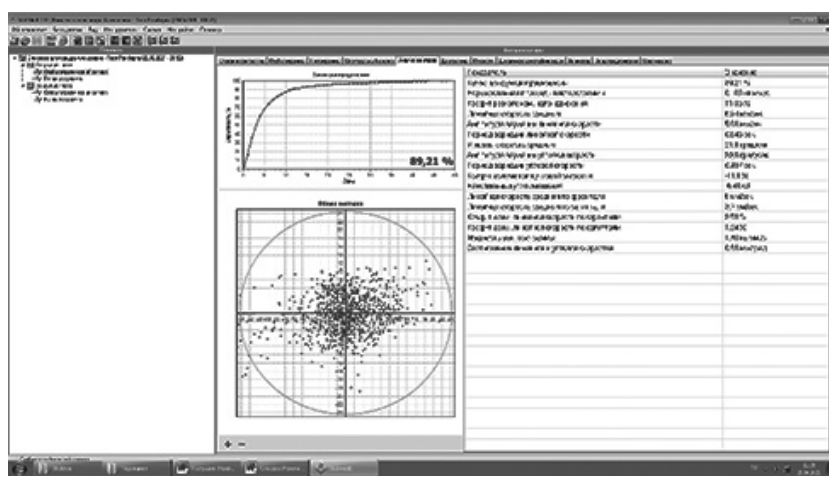

a

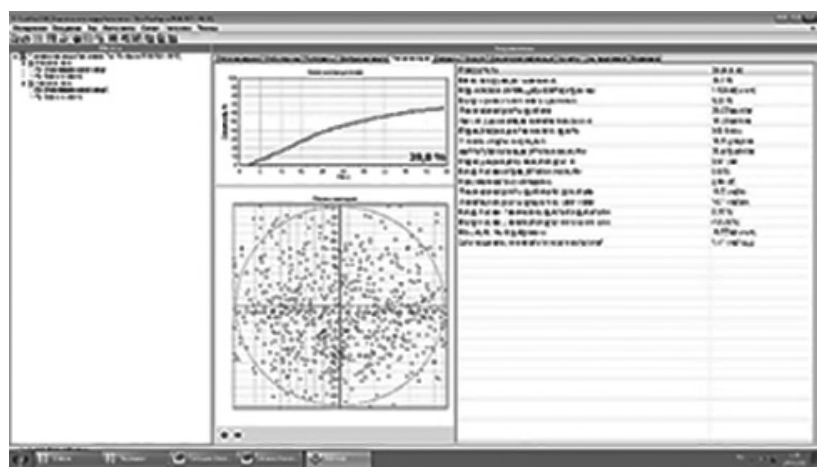

6

Рисунок 2 - Якість функції рівноваги спортсменки Є. при виконанні звичайної проби Ромберга: а - очі розплющені; б - очі заплющені (методика «Стабілан-01-2»)

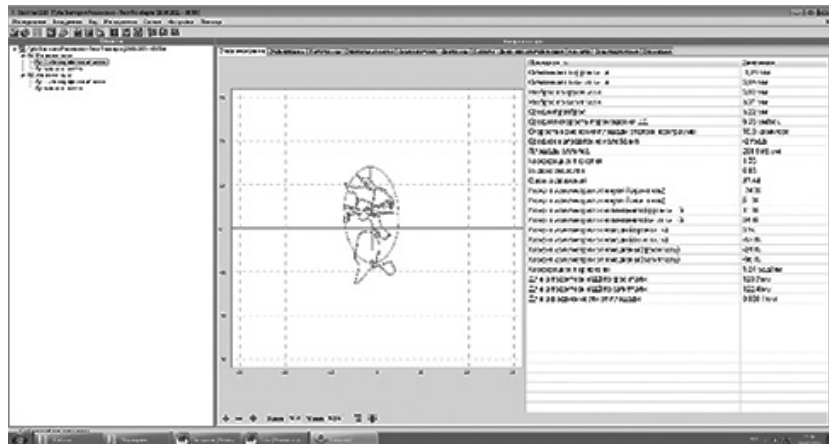

a

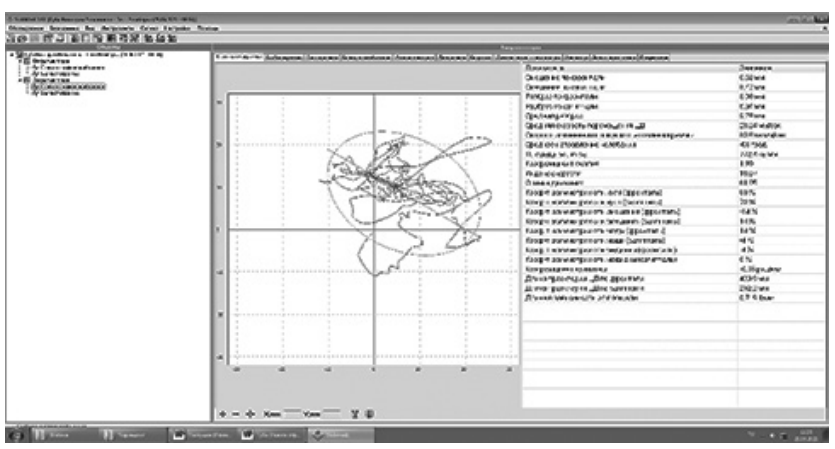

6

Рисунок 3 - Статокінезіограма та її кількісні показники при виконанні звичайної проби Ромберга спортсменкою Г.: а - очі розплющені; б - очі заплющені (методика «Стабілан-01-2»)

Отримані дані свідчать, що при порівнянні результатів проби «заплющені очі» та «розплющені очі» у спортсменки $Є$. спостерігається зміщення у фрронтальній площині на 3,49 мм вліво та зміщення в сагітальній площині на 2,65 мм назад. Величина девіації у фронтальній площині збільшилася в 4,18 раза, що вище за норму в 2,79 раза; величина девіації в сагітальній площині збільшилася в 2,51 раза, що вище за норму в 1,67 раза.

Показники розкиду по фронталі (1,99 мм), сагіталі (3,32 мм), довжина (138,32 та 459,78 мм розплющені та заплющені очі відповідно) і площа

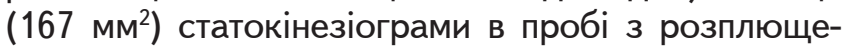
ними очима знаходяться в межах норми, тоді як показник розкиду по фронталі (8,31 мм), площа

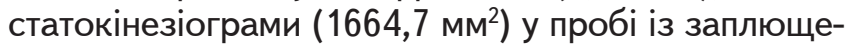
ними очами знаходяться умовно в нормі, а показник розкиду по сагіталі (8,33 мм) - поза нормою.

Індивідуальні показники статокінезіограми спортсменки Г. та графрічне зображення якості функції її рівноваги при виконанні звичайної проби Ромберга представлено на рисунках $3,4$.

При порівнянні результатів проби «заплющені очі» та «розплющені очі» у спортсменки Г. спостерігається зміщення у фронтальній пло- щині на 7,8 мм вправо і зміщення в сагітальній площині на 5,37 мм вперед. Величина девіації у фронтальній площині збільшилася в 2,65 раза, що вище за норму в 1,77 раза; величина девіації в сагітальній площині збільшилася в 1,31 раза, що відповідає нормі.

Показники розкиду по фронталі (3,02 мм),

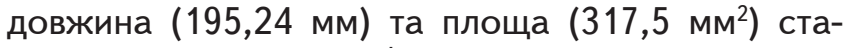
токінезіограми в пробі з розплющеними очима знаходяться в межах норми, тоді як показники розкиду по фронталі (8,03 мм), по сагіталі (6,94 мм), довжина (565,61 мм) та площа статокінезіограми $\left(1609,1 \mathrm{~mm}^{2}\right)$ у пробі із заплющеними очима знаходяться умовно в нормі. Спостерігається відхилення за показником розкиду по сагіталі (5,31 мм) у пробі з розплющеними очима, який знаходиться поза нормою.

Індивідуальні показники статокінезіограми спортсменки П. та графрічне зображення якості функції її рівноваги при виконанні звичайної проби Ромберга представлено на рисунках 5,6 .

Порівняння результатів проби «заплющені очі» та «розплющені очі» у спортсменки П. показали зміщення у фронтальній площині на 4,35 мм вправо та зміщення в сагітальній площи- 


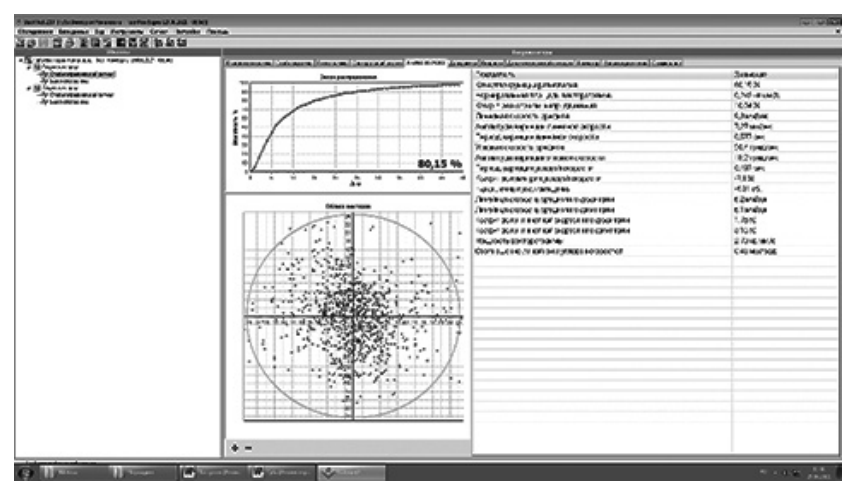

a

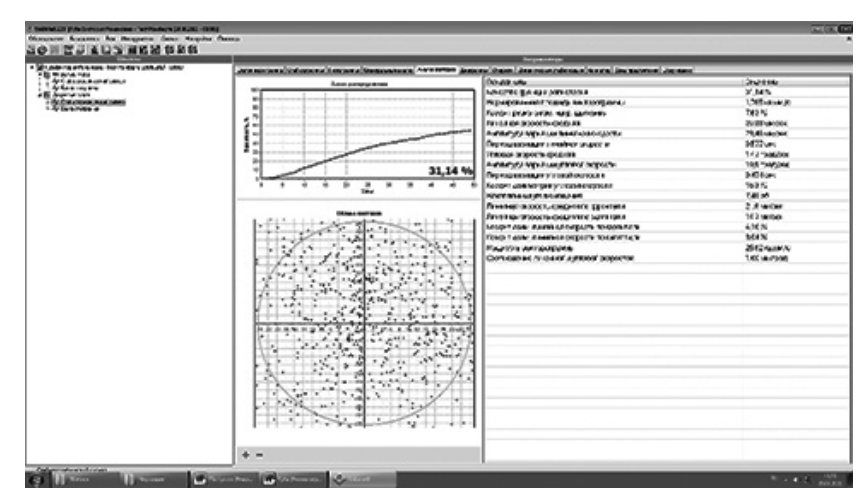

6

Рисунок 4 - Якість фрунції рівноваги спортсменки Г. при виконанні звичайної проби Ромберга: а - очі розплющені; б - очі заплющені (методика «Стабілан-01-2»)

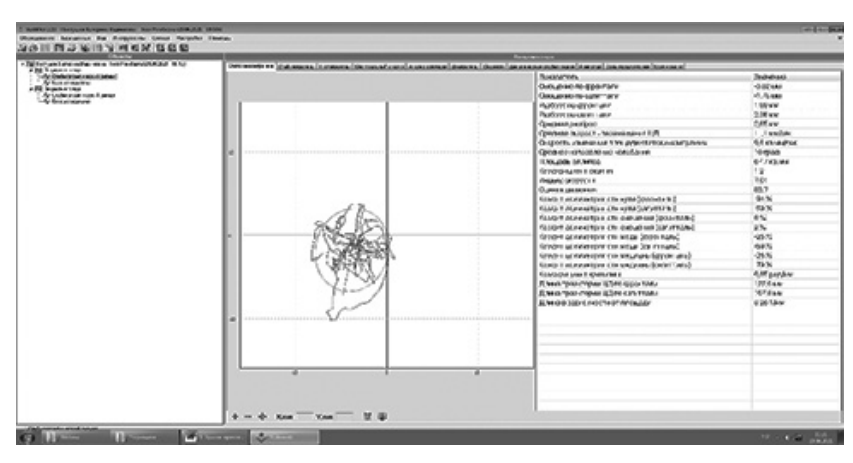

a

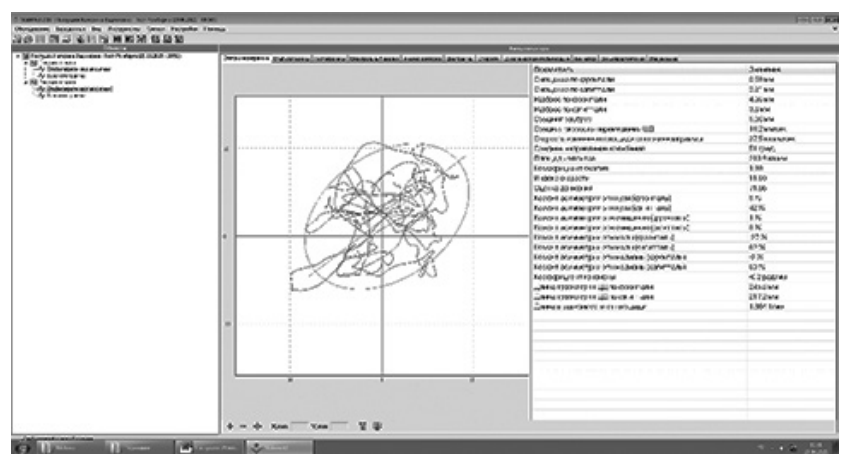

6

Рисунок 5 - Статокінезіограма та її кількісні показники при виконанні звичайної проби Ромберга спортсменкою П.: а - очі розплющені; б - очі заплющені (методика «Стабілан-01-2»)

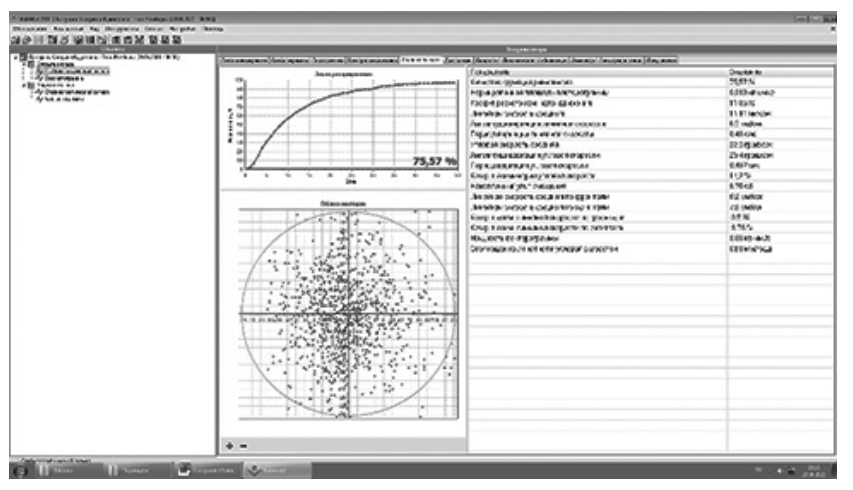

a

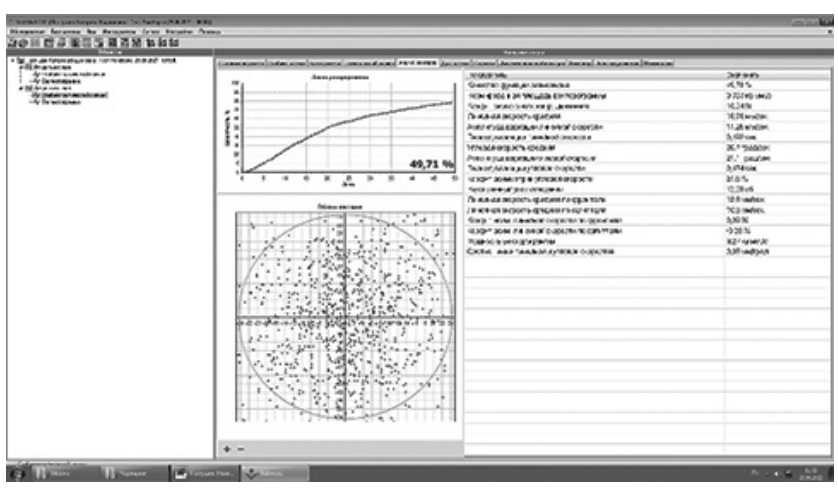

6

Рисунок 6 - Якість функції рівноваги спортсменки П. при виконанні звичайної проби Ромберга: а - очі розплющені; б - очі заплющені (методика «Стабілан-01-2»)

ні на 3,99 мм вперед. Величина девіації у фрронтальній площині збільшилася в 2,03 раза, що вище за норму в 1,35 раза; величина девіації в сагітальній площині збільшилася в 1,61 раза, що відповідає нормі.

За показниками статокінезіограми в пробі 3 розплющеними та заплющеними очима, а саме розкиду по фрронталі (1,99 та 4,03 мм відповід- но), розкиду по сагіталі (2,36 та 3,4 мм відповідно), довжині (221,48 та 363,26 мм відповідно) і площі (186,3 та 546,7 мм² відповідно) спостерігається норма.

Оцінка індивідуальних показників статокінезіограми спортсменки К. та графрічне зображення якості фрункції її рівноваги при виконанні звичайної проби Ромберга відображені на рисунках 7, 8. 


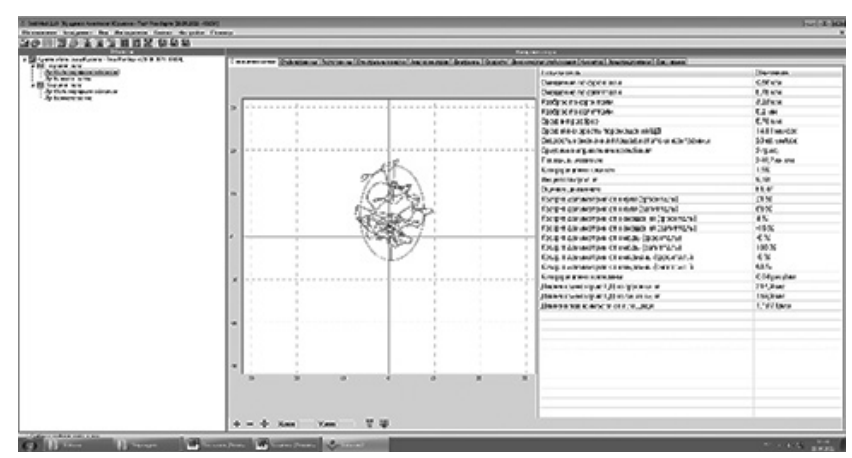

a

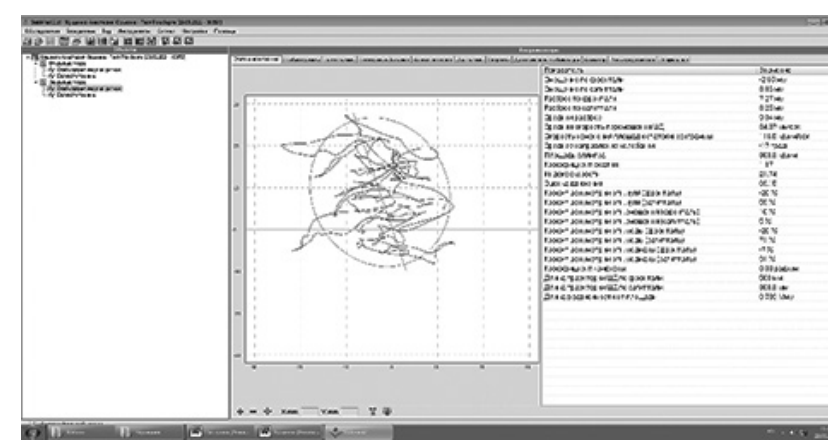

6

Рисунок 7 - Статокінезіограма та її кількісні показники при виконанні звичайної проби Ромберга спортсменкою К.: а - очі розплющені; б - очі заплющені (методика «Стабілан-01-2»)

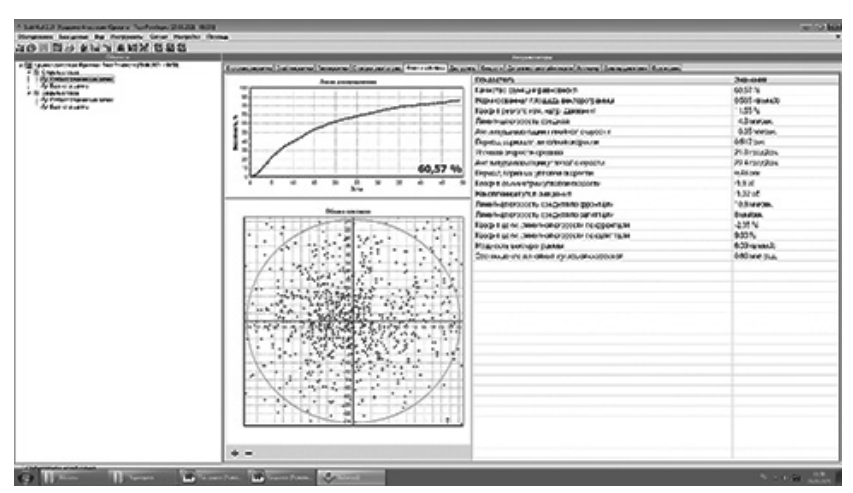

a

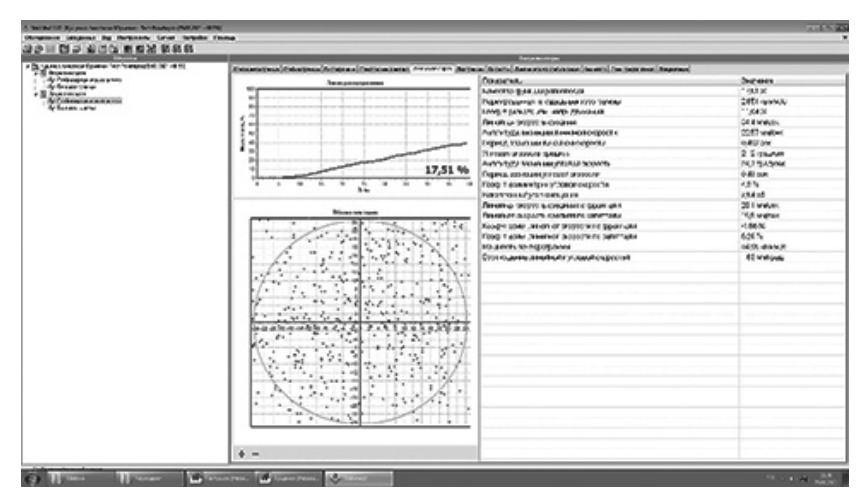

6

Рисунок 8 - Якість фрункції рівноваги спортсменки К. при виконанні звичайної проби Ромберга: а - очі розплющені; б - очі заплющені (методика «Стабілан-01-2»)

При порівнянні результатів проби «заплющені очі» та «розплющені очі» у спортсменки К. спостерігається зміщення у фронтальній площині на 3,31 мм вліво і зміщення в сагітальній площині на 3,41 мм вперед. Величина девіації у фронтальній площині збільшилася в 2,22 раза, що вище за норму в 1,48 раза; величина девіації в сагітальній площині збільшилася в 1,58 раза, що відповідає нормі.

У межах норми знаходяться показники розкиду по фрронталі (3,28 мм) та довжина (295,65 мм) статокінезіограми в пробі з розплющеними очима, тоді як практично всі інші показники знаходяться умовно в межах норми: розкид по фронталі $(7,27$ мм) у пробі із заплющеними очима, розкид по сагіталі (5,2 мм) у пробі з розплющеними очима, довжина $(685,93$ мм) у пробі із заплющеними очима та площа статокінезіограми $\left(578,1 \mathrm{mм}^{2}\right)$ у пробі з розплющеними очима. Поза нормою визначено два показники: розкид по сагіталі (8,25 мм) у пробі із заплющеними очима та

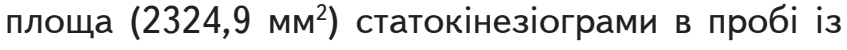
заплющеними очима.

Порівняння результатів спортсменок дозволило виявити рівень їхньої стійкості. За загаль- ний критерій ми обрали якість функції рівноваги спортсменки (табл. 1).

Аналіз отриманих даних свідчить, що у спортсменок, які спеціалізуються в дисципліні черданс-фристайл-дует, спостерігається середній рівень якості фуннцції рівноваги (60,57-89,21\%) у пробі 3 розплющеними очима та низький $(25,86-49,41 \%)$ у пробі із заплющеними очима. Це свідчить про те, що у спортсменок невисокий рівень розвитку зорового аналізатора та низький рівень розвитку пропріорецепторів. На період дослідження спортсменки вивчали нову змагальну програму, в якій особливе місце відводили елементам рівноваги, сенсорній координації.

Таблиця 1 - Порівняльний аналіз якості функції рівноваги у спортсменок, що спеціалізуються в дисципліні чер-дансфристайл-дует

\begin{tabular}{|c|c|c|c|c|}
\hline \multirow{2}{*}{$\begin{array}{l}\text { № } \\
3 / n\end{array}$} & \multirow{2}{*}{$\begin{array}{l}\text { Спорт- } \\
\text { сменка }\end{array}$} & \multicolumn{2}{|c|}{ Якість функції рівноваги, \% } & \multirow{2}{*}{ Різниця, \% } \\
\hline & & $\begin{array}{c}\text { 3 розплющеними } \\
\text { очима }\end{array}$ & $\begin{array}{c}\text { із заплющеними } \\
\text { очима }\end{array}$ & \\
\hline 1 & $\epsilon$. & 89,21 & 39,8 & 49,41 \\
\hline 2 & $\Gamma$. & 80,15 & 31,14 & 49,01 \\
\hline 3 & $\Pi$ П. & 75,57 & 49,71 & 25,86 \\
\hline 4 & $\mathrm{~K}$. & 60,57 & 17,51 & 43,06 \\
\hline
\end{tabular}


Отримані дані показали, з чотирьох спортсменок тільки три близькі за результатами одна до одної. При цьому у першої та другої спортсменок однакова різниця між пробами з розплющеними та заплющеними очима. Це дозволяє тренеру підбирати типові завдання для спортсменок. Спортсменка П. мала меншу різницю між пробами, що дозволяє спрогнозувати, що при якісній та постійній роботі на стійкість і рівновагу у неї можуть бути більш стабільні результати.

Результати досліджень було враховано при коригуванні процесу підготовки в напрямі підвищення координованості, рівноваги, роботи над пропріорецепторами та зоровим аналізатором. Для тренувань було запропоновано тренажери рівноваги, які $€$ спеціальними комп'ютерними програмами біологічного зворотного зв'язку, що базуються на візуалізації положення ЦТ або управлінні певними діями за допомогою переміщення спортсменки. Дані тренажери дозволяють розвивати різні спеціалізовані навички координації балансувальних рухів в основній стійці. У процесі тренування тренер зі спортсменками вирішує завдання розвитку опороспроможності кінцівки, удосконалення точності руху, часу руху (досягнення мети до певного часу), стабілізації руху (утримання ЦТ у певній зоні за даний час) та інші завдання, пов'язані з управлінням рухами тіла та його балансом.

Це дозволило запропонувати спортсменкам вправи на руховій платформі для підвищення якості рівноваги протягом 21 дня на 10 тренуваннях. Такі вправи спрямовані на:

- розвиток однієї вузькоспрямованої навички (наприклад, перенесення ваги тіла з однієї ноги на іншу);

- оволодіння одночасно двома (переміщення ЦТ як у сагітальній, так і фронтальній площині) і більше навичками (1 - управління значними «маховими» переміщеннями ЦТ, які дозволяють стабільно утримувати рівновагу та забезпечуються опороспроможністю нижніх кінцівок; 2 - тонкі координаційні завдання; 3 - комбіновані махово-координаційні завдання).

Для управління тренуванням було запропоновано зміну тривалості тренування, масштабу відображуваних процесів, частоти завдань.

Використання тренажерного обладнання зі зворотним біологічним зв'язком дозволило підвищити рівень якості рівноваги, що відзначилося при виконанні нової змагальної вправи: у спортсменок зменшилася кількість помилок при виконанні елементів рівноваги на 34 \%, вони продемонстрували в парі сенсомоторну координацію.

Дискусія. Недостатність сенсомоторної координації може позначатися на порушенні стій- кості тіла і системи тіл, просторово-тимчасового орієнтування тіла на опорі і без неї, темпо-ритмовій структурі, дифреренціюванні параметрів рухів. При виконанні програмних перебудов у руховій структурі складу змагальної вправи виявляються технічні помилки [9]. Сенсомоторне тренування розглядають як навчально-тренувальний процес, спрямований на розвиток і вдосконалення координації рухів спеціальними (специфрічними) координаційними вправами. Такі вправи підвищують просторові, тимчасові і силові показники системного управління рухами спортсменки. Координаційне тренування будується 3 урахуванням показників спеціальної рухової (фрізичної) і спеціальної технічної підготовленості спортсменки. В.М.Болобан [12] зазначає, що тренування будується 3 урахуванням рівня розвитку сенсомоторної координації, накопичених знань про рівень розвитку (вдосконалення) й індивідуального прояву координаційних здібностей спортсменок, наявності валідних засобів (координаційних вправ) і методів їх реалізації у тренувальній та змагальній діяльності. Координаційне тренування виступає елементом підготовки в черліденгу.

Нами підтверджено дані Д. В. Скворцова [19] про те, що незважаючи на різноманіття методів математичної обробки стабілометричного сигналу, існує ряд параметрів, які для біомеханічного аналізу рівноваги мають домінуюче значення. Їх використовують як у біомеханіці спорту, так і в більшості клінічних досліджень. Це такі параметри:

- абсолютне положення ЦТ (у системі координат досліджуваного);

- девіація ЦТ близько середнього положення;

- середня швидкість руху ЦТ;

- середня площа статокінезіограми;

- показники спектра частот.

Метод стабілографрії у спорті залишається інформативним та надійним для визначення параметрів стійкості і рівноваги, які $€$ пріоритетними в складнокоординаційних видах спорту.

У черліденгу метод стабілографії можна рекомендувати для використання в процесі контролю за стійкістю і рівновагою. Для черліденгу притаманні координаційно складні та інтенсивні рухи, що містять елементи акробатики, спортивної та художньої гімнастики, спортивних танців $[1,21,23]$. Це дозволяє сорормувати в процесі підготовки спортсменів-черлідерів значний арсенал рухових навичок координаційної складності та точності.

Висновки. Проведені дослідження та багаторічний досвід застосування методу стабілографії свідчать про високу його інфрормативність для 
складнокоординаційних видів спорту. Цей метод дозволяє визначити діяльність зорових та пропріорецептивних аналізаторів, що впливають на фуннкцію рівноваги. В черліденгу при складанні змагальної програми важливими елементами $\epsilon$ складність і точність рухів, стійкість при виконанні елементів, контроль корпуса і всіх частин тіла під час виконання рухів і елементів, перенесення ваги тіла, максимальне використання простору змагального майданчика, перебудови, взаємо-

\section{Література}

1. Андрієнко ГС, Шинкарук ОА. Особливості підготовки та проблема травматизму спортсменів в черліденгу. Інноваційні та інформаційні технології у фізичній культурі, спорті, фізичній терапії та ерготерапії [Osoblyvosti pidhotovky ta problema travmatyzmu sport-smeniv v cherlidenh. Innovatsiyni ta informatsiyni tekhnolohiyi u fizychniy kul'turi, sporti, fizychniy terapiyi ta erhoterapiyi]: Матер. III Всеукр. електронної науково-практ. конф. 3 міжнародною участю (Київ, 8 квітня 2020 р.) / ред. О. А. Шинкарук. Київ: НУФВСУ, 2020:109-111.

2. Бернштейн НА. О ловкости и ее развитии [About agility and its development]. Москва: Физкультура и спорт, 1991. 288 с.

3. Бернштейн НА. Физиология движений и активность [Physiology of movements and activity]. Москва: Наука, 1990. 495 с.

4. Блажко Н, Андрієнко Г, Шинкарук О. Моделювання підготовленості спортсменок високої кваліфікації в дисципліні чер-перфоменс джаз команда. Інноваційні та інформаційні технології у фізичній культурі, спорті, фізичній терапії та ерготерапії [Modeling the training of highly qualified athletes in the discipline of black performance jazz team. Innovative and information technologies in physical culture, sports, physical therapy and occupational therapy]: Матер. IV Всеукр. електронної науково-практ. конф. з міжнародною участю (Київ, 9 квітня 2021 р.) / ред. О. А. Шинкарук. Київ: НУФВСУ, 2021:9-10.

5. Блажко Н, Шинкарук О. Особливості виконання змагальної програми в командних дисциплінах черліденгу [Features of the competitive program in team disciplines of cheerleading]: Матер. II Всеукр. електронної конф. з міжнародною участю «Інноваційні та інформаційні технології у фізичній культурі, спорті, фізичній терапії та ерготерапії» (18 квітня 2019 р.). Київ: НУФВСУ, 2019:14-6.

6. Блажко НА, Шинкарук ОА. Компоненти підготовки кваліфікованих спортсменок у черліденгу. Молодь та олімпійський рух [Components of training qualified athletes in cheerleading. Youth and the Olympic Movement]: 3б. тез доповідей XIII Міжнар. конф. молодих вчених (16 травня 2020 р.) [Електронний ресурс]. Київ, 2020:56-7.

7. Болобан ВМ, Литвиненко ЮВ. Оцінка статодинамічної стійкості тіла та системи тіл спортсменів, які спеціалізуються у складнокоординаційних видах спорту [Assessment of statodynamic stability of the body and body system of athletes who specialize in complex coordination sports]. Teopiя і методика фізичного виховання і спорту. 2012;(2):88-92.

8. Болобан ВН, Литвиненко ЮВ, Нижниковски Т. Системная стабилография: методология и метод измерения, анализа и оценки статодинамической устойчивости тела спортсмена и системы тел [System stabilography: methodology and method of measuring, analyzing and assessing the statodynamic stability of the athlete's body and the system of bodies]. Наука в олимпийском спорте. 2012;(1):27-36.

9. Болобан ВН, Литвиненко ЮВ, Оцупок АП. Критерии оценки статодинамической устойчивости тела спортсмена и системы тел в видах спорта, сложных по координации [Criteria for assessing the statodynamic stability of the athlete's body and the body system in sports that are complex in coordination]. Физическое воспитание студентов. 2012;(4): 17-24.

10. Болобан В, Мистулова Т. Контроль устойчивости равновесия тела спортсмена методом стабилографии [Control of the stability of the дії в парі, злагоджені зміни позицій і положень тощо. Експериментальні дослідження свідчать про недостатній рівень функції рівноваги кваліфрікованих спортсменок у черліденгу, що впливає на засвоєння нової змагальної програми. Поєднання використання методу контролю за допомогою стабілографії та використання тренажерів рівноваги дозволило спортсменкам підвищити рівень рівноваги і зменшити кількість помилок при виконанні змагальної програми.

balance of the athlete's body by the method of stabilography]. Физическое воспитание студентов творческих специальностей: Сб. научн. тр. под. ред. Ермакова С. С. Харьков: ХГАДИ (ХХПИ), 2003;(2):24-33.

11. Болобан В, Мистулова Т. Стабилография: достижения, перспективы [Stabilography: achievements, prospects]. Наука в олимпийском спорте. Спец. вып. 2000:5-13.

12. Болобан ВН. Сенсомоторная координация как основа технической подготовки [Sensorimotor coordination as the basis for technical training]. Наука в олимпийском спорте. 2015;(2):73-80.

13. Гурфинкель ВС, Коц ЯМ, Шик МЛ. Регуляция позы человека [Regulation of human posture]. Москва: Наука, 1965. 256 с.

14. Зінченко IA. Побудова тренувального процесу спортсменів у черліденгу на етапі спеціалізованої базової підготовки [Construction of the training process of athletes in cheerleading at the stage of specialized basic training]: автореф. дис. ... канд. наук з фіз. виховання і спорту: 24.00 .01 «Олімпійський і професійний спорт». Харків, 2013.

15. Крикун Ю. Характеристика змагальної діяльності спортсменів у черліденгу [Characteristics of competitive activity of cheerleading athletes] Слобожанський науково-спортивний вісник. Харків: ХДАФК, 2009;2:30-5.

16. Литвиненко ЮВ, Садовски Е, Нижниковски Т, Болобан ВН. Статодинамическая устойчивость тела гимнастов высокой квалификации [Statodynamic stability of the body of highly qualified gymnasts]. Физическое воспитание студентов. 2015;(1):46-51.

17. Литвиненко ЮВ. Теоретико-практичні аспекти біомеханічного аналізу показників статодинамічної стійкості спортсменів високої кваліфікації у складнокоординаційних видах спорту [Theoretical and practical aspects of biomechanical analysis of indicators of statodynamic stability of highly qualified athletes in complex coordination sports]. Спортивний вісник Придніпров'я. 2016;(2):85-9.

18. Мистулова Т, Слива С, Миленькая С. Использование методики стабилографии в спортивной тренировке и реабилитации [Using the stabilography technique in sports training and rehabilitation]. Педагогіка, психологія та медико-біологічні проблеми фізичного виховання і спорту: $3 б$. наук. пр. за ред. Ермакова С. С. Харків: ХДАДМ (ХХПІ), 2004;(24):74-82.

19. Скворцов ДВ. Стабилометрическое исследование: краткое руководство [Stabilometric study: a short guide]. Москва: Маска, 2010. 172 с.: ил.

20. Федорчук СВ, Шинкарук ОА, Лисенко ОМ, Колосова ОВ, Горенко ЗА, Очеретько БЄ та ін. Комплексне дослідження функціонального стану спортсменів високої кваліфікації з різним стажем спортивного тренування (веслування на байдарках і каное). Молодь та олімпійський рух [Comprehensive study of the functional state of highly qualified athletes with different experience of sports training (kayaking and canoeing). Youth and the Olympic Movement]: Зб. тез доповідей XIV Міжнар. конф. молодих вчених (19 травня 2021 р.) [Електронний ресурс]. Київ, 2021:218-9.

21. Шинкарук О, Блажко Н. Розвиток рухових якостей у спортсменів різної статі та їх значущість в системі підготовки у черліденгу [Development of motor skills in athletes of different sexes and their importance in the system of training in cheerleading]. ТМФВ. 2020;1:39-41. https://doi.org/10.32652/ tmfvs.2020.1.34-41

22. Шинкарук О, Блажко Н, Андрієнко Г. Види підготовки спортсменок у черліденгу. Молодь та олімпійський рух [Types of training athletes in 
cheerleading. Youth and the Olympic movement]: Зб. тез доповідей XIV Міжнар. конф. молодих вчених (19 травня 2021 р.) [Електронний ресурс]. Київ, 2021:157-8

23. Шинкарук ОА, Блажко НА. Моделювання фізичної підготовленості в складнокоординаційних видах спорту та черліденгу. Інноваційні та інформаційні технології у фрізичній культурі, спорті, фізичній терапії та ерготерапії NA [Modeling of physical fitness in complex coordination sports and cheerleading. Innovative and information technologies in physical culture, sports, physical therapy and occupational therapy: Proceedings of the III All-Ukrainian electronic scientific-practical conference with international participation]: Матер. III Всеукр. електронної науково-практ. конф. з міжнародною участю (Київ, 8 квітня 2020 р.) / ред. О. А. Шинкарук. Київ: НУФВСУ, 2020:43-4.

24. Шинкарук ОА, Блажко НА. Особливості змагальних дисциплін у черліденгу [Features of competitive disciplines in cheerleading]: Матер. XII міжнар. конф. «Молодь та олімпійський рух». Київ, 2019:193-4.

25. Byshevets N, Shynkaruk O, Stepanenko O, Gerasymenko S, Tkachenko S, Synihovets I et al. Development skills implementation of analysis of variance at sport-pedagogical and biomedical researches. Journal of Physical Education and Sport. 2019;19(6);311:2086-90. DOI: 10.7752/jpes.2019.s6311 https://efsupit.ro/images/stories/november2019/Art\%20311.pdf

26. Byshevets N, lakovenko O, Stepanenko O, Serhiyenko K, Yukhno $\mathrm{Yu}$, Goncharova N et al. Formation of the Knowledge and Skills to Apply

anna_andrienko@yahoo.com

shi-oksana@ukr.net

ylitvinenko.biomechanics@gmail.com
Non-Parametric Methods of Data Analysis in Future Specialists of Physical Education and Sports. Sport Mont. 2021;19;:S2:171-5.

27. Byshevets N, Denysova L, Shynkaruk O, Serhiyenko K, Usychenko V, Stepanenko O, Syvash I. Using the methods of mathematical statistics in sports and educational research. Journal of Physical Education and Sport. 2019;19(3);148:1030-34. DOI: 10.7752/jpes.2019.s3148 https://efsupit.ro/ images/stories/iunie2019/Art\%20148. pdf

28. Gagey PM, Weber B. Posturologie. Regulation et dereglements de la station debout. Paris: Masson, 1995. 145 p.

29. Hrysomallis C, McLaughlin P, Goodman C. Relationship between statics and dynamic balance test among elite Australian footballers. J. Sci Med. Sport, 2006. Aug;9(4):288-91.

30. Kostiukevych V, Lazarenko N, Shchepotina N, Vozniuk T, Shynkaruk O, Voronova V et al. Factor Analysis of Special Qualities of Elite Field Hockey Players. Sport Mont. 2021;19;:S2:41-7.

31. Sarabon N. Balance and Stability Training. NSCA/s Guide to Program Design. Editor Jay R. Hoffman. Human Kinetics, 2012:185-212.

32. Winter DA. A. B. C. of balance during standing and walking. Univ. of Waterloo press, $1995.56 \mathrm{p}$.

33. Winter DA. Human balance and posture control during standing and walking. Gait Posture. 1995;3:193-214. 